\title{
Biologists angered by database access fee
}

\section{Alison Abbott}

Geneticists are up in arms over the introduction of a subscription fee for access to the protein databases owned and maintained by Incyte Genomics, a private company based in Palo Alto, California.

The databases, which contain information about protein structure and function in important model organisms studied by biologists, had been free to academics. But Incyte last month introduced an annual access charge of $\$ 2,000$ per laboratory - a move that has already prompted an effort to secure more funding for public databases.

Many biologists claim that they would be prepared to pay a small fee to support the maintenance of high-quality databases even though most of the data were generated by the researchers themselves in publicly funded labs. But some are crying foul over the size of Incyte's fee. "The fee is simply too high for small laboratories," says Gustav Ammerer, a yeast geneticist at the University of Vienna.

Incyte's database collection, known as the Proteome BioKnowledge Library, covers model organisms such as yeast (Saccharomyces cerevisiae and Schizosaccharomyces pombe) and the nematode Caenorhabditis elegans, and also features some mammalian and microbial databases.

The library was founded in 1995 by James Garrels, whose company, Massachusettsbased Proteome, offered academics free access to the data but charged industrial users. Garrels sold the company to Incyte at the end of 2000, when he assured geneticists that the databases would remain free on the web to academics. Incyte was unavailable for comment on the reasons for the change.

The move has already caused researchers some difficulties. Peer Bork, a bioinformaticist at the European Molecular Biology Laboratory in Heidelberg, had to withdraw some information from a recent paper (C. von Mering et al. Nature 417,399-403;2002) just before it was published, when Incyte changed the terms under which the data in it could be shared. The paper compared different analyses of protein interactions in yeast.

But with the introduction of the access fee, restrictions have become even tighter. "Now I don't know how to respond to enquiries about the data we used," Bork says, adding that he is unsure whether he can share his data with other researchers.

Bork and other researchers say that Incyte is just filling a void caused by a lack of funding for public-sector databases. Annotation - the process of assigning functional and other information to the genes and proteins in databases - is a skill that needs to be paid for, Bork says. "If a company is prepared to fill in the niche, then the argument is only with the pricing policy," he says.
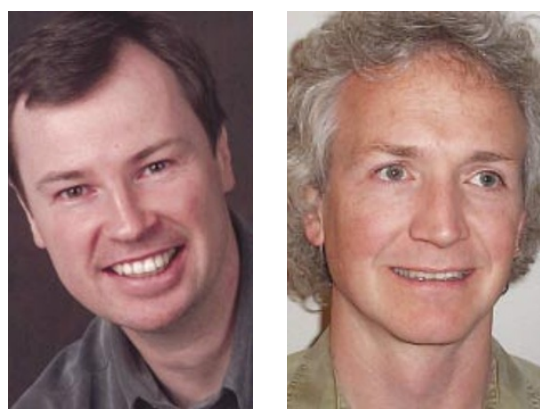

Peer Bork (left) and Michael Cherry would like to see more money for public protein databases.

Peter Okkema, a biologist at the University of Illinois at Chicago, agrees that the controversy over commercial databases "is a matter of price rather than principle". When he learned in May that a subscription fee for Incyte's databases was imminent, he sent a letter signed by 160 scientists to Incyte's board of directors requesting reconsidera- tion, but received no reply, he says. The silence, he adds, reveals a further problem with Incyte - its alleged lack of communication with the scientific community.

Chris Hogue, who runs BIND, a proteininteraction database based at the Samuel Lunenfeld Research Institute in Toronto, says that active input from researchers often isn't enough to keep a database going. Researchers "usually prefer someone else" to do the work needed to keep the database in shape. "My plea to researchers is to take database curation into your own hands," he says. "Everyone has to pitch in if they are to be freely available."

In the United States, scientists running model-organism databases in the public sector are lobbying for more support from the National Institutes of Health. Michael Cherry of Stanford University, who helps to run the Saccharomyces Genome Database there, says that more funds for its expansion would help to compensate those who cannot afford to access Incyte's yeast database.

\section{Japan gives scientists political role}

\section{David Cyranoski, Tokyo}

The scandal that has surrounded the discovery of bovine spongiform encephalopathy (BSE) in Japanese cattle has prompted the country's government to hand over a rare degree of responsibility to scientists. As of next year, ministers will follow the recommendations of a newly created committee of researchers when it comes to food-safety issues.

"It's an unprecedented amount of authority for scientists," says Takashi Onodera, an immunologist at the University of Tokyo. "The committee members will be like government officials."

Japan's first case of BSE was confirmed last September. The likely cause was contaminated meat and bone-meal that was imported from Britain and used as cattle feed. But a scandal erupted when the government was criticized for allowing such feed to be imported until 1996, despite it being banned in Europe in 1990 . Four cases of BSE have now been confirmed.

This April, an independent report commissioned by the agriculture ministry found that the government had failed to take the opinions of food-safety specialists into account, and that the close relationship between politicians, bureaucrats and the beef industry had prevented it from responding appropriately to the threat of BSE.

The new committee will consist of five or six specialists in fields such as microbiology and food additives. It will submit its reports to the minister in charge of public safety.

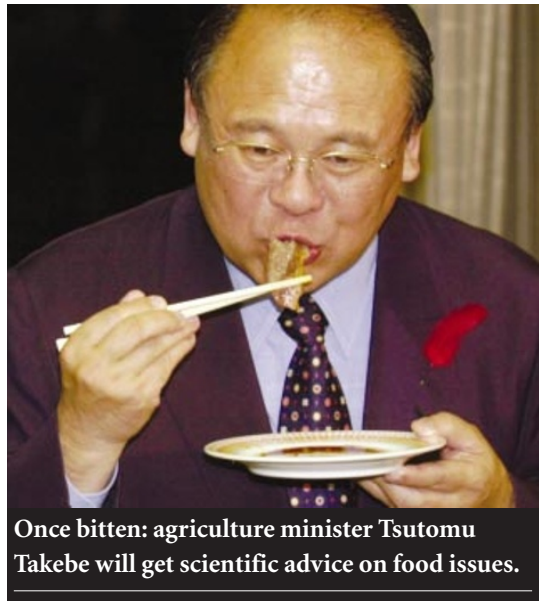

These reports are expected to have significant binding power. "If I don't follow the committee's recommendations, I'll get fired," says agriculture minister Tsutomu Takebe.

But some researchers are worried that the government will fill the committee with scientists who will tell ministers whatever they want to hear. "Judging from the government's past record, they will probably avoid anyone who would raise severe criticism," says Masanori Fukushima, an epidemiologist at Kyoto University.

Pleas to include a representative of a consumer group on the committee have already been rejected. "We want to keep the committee scientific," an agriculture ministry official explains. 